\title{
Malignant Colon Neoplasm
}

National Cancer Institute

\section{Source}

National Cancer Institute. Malignant Colon Neoplasm. NCI Thesaurus. Code C9242.

A primary or metastatic malignant neoplasm that affects the colon. Representative examples include carcinoma, lymphoma, and sarcoma. 